\title{
PENGARUH STRATEGI PEMBELAJARAN DAN KEMANDIRIAN BELAJAR TERHADAP HASIL BELAJAR SEJARAH KEBUDAYAAN ISLAM SISWA MADRASAH ALIYAH NEGERI SIMALUNGUN
}

\author{
Nurhayatimah Sinaga \\ Guru Madrasah Aliyah Negeri Simalungun
}

\begin{abstract}
This study aims to find out and to describe: (1) the learning outcomes of SKI students taught using CIRC learning strategies are higher than the learning outcomes of students taught using expository learning strategies, (2) SKI learning outcomes between students with high learning independence than results student learning with low learning independence, and (3) the interaction between learning strategies and learning independence towards learning outcomes of SKI. The population of this research is all students of class X MAN Simalungun consists of 5 classes. Based on Cluster Random sampling technique. The research instrument is a test used to obtain learning outcome data and questionnaires to obtain data on student learning independence. The analysis technique is two-way Anova at significance $\alpha=0.05$ followed by the Scheffe test. The results showed: (1) the average SKI learning outcomes of students taught with CIRC learning strategies $(\bar{X}=29.32)$ were higher than the average SKI learning outcomes of students taught with expository learning strategies $(\bar{X}=27)$ with $\mathrm{F}_{\text {count }}=13,32>\mathrm{F}_{\text {table }}=4.00$, (2) the average SKI learning outcomes of students with high learning independence $(\bar{X}=29.90)$ are higher than students' SKI learning outcomes with low learning independence $(\bar{X}=26.20)$, with $\mathrm{F}_{\text {count }}=10.41>\mathrm{F}_{\text {table }}=$ 4.00 , and (3) there is an interaction between learning and independence learning strategies with $\mathrm{F}_{\text {count }}=12.51>\mathrm{F}_{\text {table }}=4.00$.
\end{abstract}

Keyword: Learning Strategies, Learning Independence and Learning Outcomes

\section{Pendahuluan}

Pembelajaran CIRC dalam bidang studi Sejarah Kebudayaan Islam menekankan pembelajaran di mana siswa menemukan sendiri yang dipelajarinya, bukan mengetahui dari guru saja. Sedangkan pada strategi pembelajaran langsung pada pembelajaran Sejarah Kebudayaan Islam lebih menekankan penyampaian informasi atau ceramah yang dilakukan guru, sehingga terdapat kecenderungan siswa hanya sebagai pendengar pasif dan pencatat saja di mana fungsi guru merupakan satusatunya sumber belajar sehingga penumpukan informasi yang 
disampaikan guru melalui ceramah sehingga kondisi yang demikian membuat siswa jenuh dan berakibat kepada pencapaian hasil belajar yang kurang maksimal.

Di samping faktor strategi pembelajaran yang dikenal juga dengan istiah faktor eksternal yang mempengaruhi pencapaian Sejarah Kebudayaan Islam siswa, maka faktor internal yaitu faktor yang berasal dari diri siswa berupa karakteristik siswa turut mempengaruhi pencapaian hasil belajar Sejarah Kebudayaan Islam. Karakteristik siswa dapat berupa gaya belajar, kemandirian, gaya kognitif, kemampuan awal, minat dan sebagainya. Salah satu karakteristik siswa yang dikaji dalam penelitian ini adalah kemandirian belajar yang dibedakan atas kemandirian belajar tinggi dan kemandirian rendah.

Perbedaan kemandirian belajar yang melekat pada diri siswa berakibat pada perbedaan kemampuan siswa dalam menyerap materi ajar Sejarah Kebudayaan Islam. Dalam hal ini siswa yang dengan kemandirian belajar tinggi akan memberikan dampak untuk berinisiatif, kemauan belajar kuat serta kesiapan belajar yang dapat di atas sendiri tanpa tergantung dengan orang lain, hal ini sebaliknya terjadi pada siswa dengan tingkat kemandirian belajar rendah.

Adanya perbedaan tingkat kemandirian belajar antara siswa dengan tingkat kemandirian tinggi dan siswa dengan tingkat kemandirian rendah hal ini diduga memberikan pengaruh yang berbeda terhadap perolehan hasil belajar Sejarah Kebudayaan Islam siswa. Hal ini disebabkan karakteristik siswa dengan tingkat kemandirian belajar tinggi akan mengerjakan dengan sungguh-sungguh tugas yang diberikan guru karena hal tersebut menantangnya untuk mencari penyelesaian sedangkan siswa dengan tingkat kemandirian belajar rendah cenderung mengharapkan dan membutuhkan bantuan guru atau orang lain dalam menyelesaikannya.

Pemilihan strategi pembelajaran yang tepat dibutuhkan dan harus disesuaikan dengan kemandirian belajar siswa, karena mempelajari materi Sejarah Kebudayaan Islam yang cukup padat dituntut kemandirian belajar siswa dalam mencari sumber-sumber lain. Oleh karena itu, kemandirian belajar siswa adalah salah satu komponen yang harus diperhatikan dengan seksama oleh guru dalam mengidentifikasi kemampuan yang dimiliki peserta didiknya yang akan membantu dalam menentukan materi, strategi, metode dan media yang tepat untuk digunakan. Hal ini perlu dilakukan agar pembelajaran yang disampaikan dapat menarik perhatian siswa dan setiap detik yang berlangsung dalam 
kegiatan pembelajaran yang dilakukan akan bermakna dan tidak membosankan bagi siswa.

\section{KAJIAN TEORETIS}

\section{Strategi Pembelajaran}

Gerlach dan Ely sebagaimana dikuti Uno (2008:1) menjelaskan strategi pembelajaran merupakan cara-cara yang dipilih untuk menyampaikan metode pembelajaran dalam lingkungan pembelajaran tertentu yang meliputi sifat lingkup dan urutan kegiatan pembelajaran yang dapat memberikan pengalaman belajar peserta didik.

Strategi pembelajaran menurut Kemp sebagaimana Sanjaya, (2013:187) adalah suatu kegiatan pembelajaran yang harus dikerjakan guru dan siswa agar tujuan pembelajaran dapat dicapai secara efektif dan efisien. Seels dan Richey (1994:34) menjelaskan bahwa strategi pembelajaran adalah spesifikasi untuk menyeleksi serta mengurutkan peristiwa belajar atau kegiatan pembelajaran dalam suatu pelajaran. Aktivitas pembelajaran meliputi penyajian materi, pemberian contoh, pemberian latihan, serta pemberian umpan balik. Agar tujuan pembelajaran tercapai secara optimum maka semua aktivitas harus diatur dengan mempertimbangkan karakteristik peserta didik, media, dan situasi di sekitar proses pembelajaran

Strategi pembelajaran merupakan pemilihan atas berbagai jenis latihan tertentu yang sesuai dengan tujuan pembelajaran yang ingin dicapai (Gropper dalam Uno, 2008:1). Selanjutnya menurut Siregar dan Nara (2011:77) strategi pembelajaran adalah cara sistematis yang dipilih dan digunakan seorang pembelajaran untuk menyampaikan materi pembelajaran, sehingga memudahkan pembelajaran mencapai tujuan pembelajaran tertentu.

Reigeluth sebagaimana dikutip Rusmono (2012:21) menjelaskan strategi pembelajaran merupakan pedoman umum yang berisi komponenkomponen yang berbeda dari pembelajaran agar mampu mencapai keluaran yang diinginkan secara optimal di bawah kondisi-kondisi yang diciptakan. Melalui penerapan strategi pembelajaran diharapkan hasil pembelajarannya dapat berlangsung secara efektif dan efisien serta memiliki daya tarik tersendiri.

Sagala (2012:222) menjelaskan strategi pembelajaran adalah polapola umum kegiatan guru, murid dalam perwujudan kegiatan belajarmengajar untuk mencapai tujuan yang telah digariskan. Selanjutnya dijelaskan Sagala bahwa strategi pembelajaran meliputi: (1) menetapkan 
spesifikasi dan kualifikasi perubahan prilaku belajar, (2) menentukan pilihan berkenaan dengan pendekatan terhadap masalah belajarmengajar, memilih prosedur, metode dan teknik belajar-mengajar, dan (3) norma dankriteria keberhasilan kegiatan belajar-mengajar.

\section{Strategi Pembelajaran Cooperative Integrated Reading And Composition}

Strategi pembelajaran cooperative integrated reading and composition (CIRC) merupakan salah satu tipe yang terdapat dalam pembelajaran kooperatif. Dalam hal ini Arends (2008:76) menjelaskan pembelajaran kooperatif adalah strategi yang unik di antara strategistrategi pengajaran lainnya karena menggunakan struktur tujuan, tugas dan reward yang berbeda untuk mendukung pembelajaran siswa.

Slavin (2005:78) menjelaskan pembelajaran CIRC adalah sebuah program pembelajaran yang komprehensif untuk pengajaran membaca, menulis dan seni berbahasa yang difokuskan pada kurikulum dan pada metode-metode pengajaran. Dalam strategi pembelajaran CIRC, siswa ditempatkan dalam kelompok-kelompok, dalam kelompok ini tidak dibedakan atas jenis kelamin, suku/bangsa, atau tingkat kecerdasan siswa. Jadi, dalam kelompok kecil ini sebaiknya ada siswa yang pandai, sedang atau lemah, dan masing-masing siswa merasa cocok satu sama lain.

Lebih lanjut Slavin (2005:79) menjelaskan bahwa tujuan dari penerapan pembelajaran CIRC adalah untuk lebih meningkatkan kemampuan siswa membaca dan menerima umpan balik dari kegiatan membacanya dan saling merespon kegiatan membaca yang dilakukan siswa.

Hal yang sama dipertegas oleh Rahim (2005:154) bahwa CIRC bisa meningkatkan hasil belajar siswa yang rendah. Di samping itu berdasarkan pada beberapa penelitian, siswa juga bisa membuat dan menjelaskan prediksi tentang bagaimana masalah bisa diselesaikan dan meringkaskan unsur-unsur utama suatu cerita kepada unsur cerita lainnya.

Unsur-unsur yang terdapat dalam dengan pembelajaran CIRC dijelaskan Slavin (2005:80) yaitu: (1) Tim, (2) membaca berpasangan, (3) menulis isi teks, (4) mengucapkan kata-kata dengan keras, (5) makna kata, (6) menceritakan kembali isi teks, (7) ejaan (8) pemeriksaan oleh pasangan, dan (9) tes. 


\section{Strategi Pembelajaran Ekspositori}

Sanjaya (2014:179) menjelaskan strategi pembelajaran ekspositori adalah strategi pembelajaran yang menekankan kepada proses penyampaian materi secara verbal dari seorang guru kepada sekelompok siswa dengan maksud agar siswa dapat menguasai materi pelajaran secara optimal. Selanjutnya Gulo (2008:11) menjelaskan strategi pembelajaran ekspositori dilakukan guru mengolah secara tuntas pesan/materi sebelum disampaikan di kelas sehingga peserta didik tinggal menerima saja.

Rusmono (2012:66) menjelaskan strategi pembelajaran ekspositori merupakan bentuk dari pendekatan pembelajaran yang berorientasi kepada guru, karena dalam strategi ini guru memegang peran yang sangat dominan. Melalui strategi ini guru menyampaikan materi pelajaran secara terstruktur dengan harapan materi pelajaran yang disampaikan dapat dikuasai siswa dengan baik.

Langkah-langkah penerapan strategi pembelajaran ekspositori dijelaskan Sanjaya (2014:185) sebagai berikut:

1. Persiapan (preparation).

Tahap persiapan berkatan dengan mempersiapkan siswa untuk menerima pelajaran. Keberhasilan pelaksanaan pembelajaran dengan menggunakan strategi pembelajaran ekspositori sangat bergantung pada langkah persiapan. Tujuan yang ingin dicapai dalam melakukan persiapan adalah: (a) mengajak siswa keluar dari kondisi mental yang pasif, (b) membangkitkan motivasi dan minat siswa untuk belajar, (c) merangsang dan menggugah rasa ingin tahu siswa, dan (d) menciptakan suasana dan iklim pembelajaran yang terbuka.

2. Penyajian (presentation).

Langkah penyajian adalah langkah penyampaian materi pelajaran sesuai dengan persiapan yang telah dilakukan.

3. Menghubungkan (corelation).

Langkah ini adalah langkah menghubungkan materi pelajaran dengan pengalamana siswa atau dengan hal-hal lain yang memungkinkan siswa dapat menangkap keterkaitannya dalam struktur pengetahuan yang telah dimilikinya.

4. Menyimpulkan (generalization).

Menyimpulkan adalah tahapan untuk memahami inti dari materi pelajaran yang telah disajikan.

5. Penerapan (aplication). 
Langkah aplikasi adalah langkah unjuk kemampuan siswa setelah mereka menyimak penjelasan guru.

\section{Kemandirian Belajar.}

Kemandirian merupakan sebuah konsep yang mengacu dan menunjuk kepada prilaku individu dan prilaku tersebut umumnya merupakan manifestasi dari kondisi psikis. Kajian mengenai kemandirian berkaitan dengan kajian konsep diri. Konsep diri merupakan terjemahan dari "self concept". Dalam hal ini Johnson dan Medinus (1989:74) menyatakan: konsep diri adalah sikap yang dimiliki individu atas diri pribadinya yang ditunjukkan dalam tingkah laku. Dengan demikian dapatlah dimaknai bahwa sikap seseorang terhadap kondisi pisiknya maupun terhadap kondisi prilakunya dalam hal ini termasuk sikap seseorang terhadap kemandiriannya.

Havighurst sebagaimana dikutip Yamin dan Sanan (2010:113) bahwa kemandirian terdiri dari beberapa aspek yaitu: (1) emosi, aspek ini ditunjukkan dengan kemampuan mengontrol emosi dan tidak tergantungnya kebutuhan emosi dari orang lain, (2) ekonomi, aspek ini ditunjukkan dengan kemampuan mengatur ekonomi dan tidak tergantungnya kebutuhan ekonomi kepada orang lain, (3) intelektual, aspek ini ditunjukkan dengan kematangan untuk mengtatasi berbagai masalah yang dihadapi, dan (4) sosial, aspek ini ditunjukkan dengan kemampuan untuk mengadakan interaksi dengan orang lain dan tidak tergantung atau menunggu aksi dari orang lain.

Yamin dan Sanan (2010:117) siswa dikatakan mandiri apabila memiliki ciri-ciri: (1) menemukan diri atau identitas diri, (2) memiliki inisiatif, (3) membuat petimbangan-pertimbangan dalam bertindak, (4) bertanggung jawab atas tindakannya, dan (5) dapat mencukupi kebutuhan-kebutuhan sendiri. Selanjutnya Bernadib sebagaiman dikutip Yamin dan Sanan (2010:118) menjelaskan karakteristik kemandirian yaitu: (1) prilaku mampu berinisiatif, (2) mampu mengatasi hambatan/masalah, (3) mempunyai rasa percaya diri, dan (4) dapat melakukan sesuatu sendiri tanpa bantuan orang lain.

Ausubel sebagaimana dikutip Masrun (1986:120) menyatakan kemandirian (independency) dapat dibedakan atas dua golongan, yaitu: (1) Volitional independency. Individu yang memiliki kecenderungan volitional independency, tidak tergantung kepada orang lain, khususnya terhadap orang tuanya untuk mengambil keputusan. Mungkin mereka membutuhkan informasi dari orang lain, tetapi secara pribadi mereka 
bertanggungjawab terhadap keputusan yang diambil, dan (2) Executive independency. Individu yang memiliki kecenderungan executive independency, akan melakukan sesuatu dan menyelesaikan untuk dirinya sendiri, bukan karena orang lain. Individu yang independen baik secara volitional maupu secara executive ditandai dengan kemampuan menyelesaikan masalah secara rasional dan tidak bergantung pada orang lain dan bahkan kepada orangtuanya sekalipun.

Prilaku mandiri tercermin dalam prilaku yang sesuai dengan kehendak sendiri menyatakan buah pikiran sendiri, bebas dalam mengambil keputusan merasa mempunyai kebebasan untuk mengerjakan segala sesuatunya sesuai dengan kebutuhannya, menghindari situasi dimana ia diharapkan menyesuaikan dirinya dan mengerjakan sesuatu tanpa memperdulikan apa yang dipikirkan orang lain. Sebaliknya prilaku tidak mandiri tercermin dalam mendapatkan saran dari orang lain, mengikuti petunjuk dan mengerjakan seperti yang diharapkan, menerima kepemimpinan orang lain, menyesuaikan diri dengan kebiasaan dan menghindari perubahan-perubahan kebiasaan serta membiarkan orang lain membuat keputusan.

Faktor yang mempengaruhi kemandirian menurut Suryabrata (1997:184) adalah dari aspek kepribadian. Salah satu klasifikasi aspek kepribadian dikelompokkan menjadi dua kelompok yakni aspek kognitif dan non-kognitif. Aspek kognitif adalah kepribadian yang merupakan ability, sedangkan non-kognitif adalah sebaliknya yaitu kepribadian yang bukan merupakan ability. Dalam hal ini kemandirian dipandang sebagai aspek kepribadian yang mengandung aspek non-kognitif.

Sementara itu Yamin dan Sanan (2010:121) menjelaskan mengenai faktor yang mempengaruhi perkembangan kemandirian seseorang yaitu faktor lingkungan keluarga, lingkungan sekolah dan lingkungan sosial. Selanjutnya Johnson dan Medinnus (1989:75) menyatakan kemandirian dipengaruhi oleh faktor kematangan dan belajar. Dalam hal ini belajar diartikan sebagai sebuah interaksi antara individu dengan lingkungannya baik lingkungan keluarga, sekolah dan masyarakat. Perbedaan perlakuan yang diterima individu dari lingkungan keluarga, sekolah dan masyarakat berpengaruh terhadap kemandirian individu tersebut.

\section{Hasil Belajar.}

Hasil belajar, Kemp (1994:105) menjelaskan hasil belajar akan terlihat dengan adanya tingkah laku baru pada tingkat kemampuan berpikir atau kemampuan jasmaniah. Sedangkan Djamarah dan Zain 
(2002:79) menjelaskan bahwa hasil belajar adalah penguasaan peserta didik terhadap bahan/materi pelajaran yang telah diberikan ketika proses mengajar berlangsung. Bahan atau materi pelajaran kemudian selanjutnya diujikan kepada siswa untuk mengetahui penguasaannya.

Howard Kingsley dalam Sudjana (2002:165) menjelaskan tiga macam hasil belajar, yakni: keterampilan dan kebiasaan, pengetahuan dan pengertian, dan sikap dan cita-cita, yang masing-masing tipe dapat diisi dengan bahan yang ditetapkan dalam kurikulum sekolah.

Bloom dkk dalam Arikunto (2002:154) membagi tipe hasil belajar kepada tiga kelompok, yaitu: (1) domain kognitif terdiri dari enam tingkatan yaitu: pengetahuan, pemahaman penerapan, analisis, sintesis dan evaluasi. (2) domain afektif yaitu: penerimaan, tanggapan, ) penghargaan, pengorganisasian, dan karakterisasi, dan domain psikomotor terdiri: meniru, manipulasi, ketepatan gerakan, artikulas dan naturalisasi.

\section{METODOLOGI PENELITIAN}

Penelitian ini dilaksanakan di Madrasah Aliyah Negeri (MAN) Simalungun. Metode yang dipergunakan dalam penelitian ini adalah metode quasi-eksperimen. Desain penelitian yang digunakan dalam penelitian ini adalah faktorial $2 \times 2$. Populasi penelitian adalah seluruh siswa kelas $X$ MAN Simalungun yang terdiri dari 5 kelas. Teknik penentuan sampel digunakan cluster random sampling. Instrumen dan teknik pengumpulan data dalam penelitian yaitu tes dan angket. Tes dilakukan untuk mengumpulkan data hasil belajar Sejarah Kebudayaan Islam sedangkan angket untuk menjaring data kemandirian belajar. Pengujian hipotesis penelitian yang dilakukan dengan menggunakan teknik analisis varians (ANAVA) dua jalur.

\section{HASIL PENELITIAN}

Hasil penelitian menunjukkan: (1) hasil belajar Sejarah Kebudayaan Islam siswa Madrasah Aliyah Negeri Simalungun yang diajar dengan strategi pembelajaran CIRC diketahui mean $=29,32$; modus $=30,99$; median $=29,85$; varians $=13,62$; simpangan baku $=3,69$; skor maksimum = 36; dan skor minimum = 21, (2) hasil belajar Sejarah Kebudayaan Islam siswa Madrasah Aliyah Negeri Simalungun yang diajar dengan strategi pembelajaran ekspositori diketahui mean $=27$; modus $=26,00$; median $=26,60$; varians $=15,72$; simpangan baku $=3,96$; skor maksimum $=34$; dan skor minimum $=19$, (3) hasil belajar Sejarah Kebudayaan Islam bagi 
siswa dengan kemandirian belajar tinggi diketahui mean $=29,90 ;$ modus $=$ 30,90; median $=30,12$; varians $=9,57$; simpangan baku $=3,09$; skor maksimum $=36$; dan skor minimum $=23$, (4) hasil hasil belajar Sejarah Kebudayaan Islam siswa Madrasah Aliyah Negeri Simalungun dengan kemandirian belajar rendah yaitu mean $=26,20$; modus $=25,85$; median $=$ 26,00; varians $=14,09$; simpangan baku =3,75; skor maksimum $=34$; dan skor minimum $=19$, (5) hasil belajar Sejarah Kebudayaan Islam siswa yang diajar dengan strategi pembelajaran CIRC dan kemandirian belajar tinggi diketahui mean $=31,38$; modus $=31,30$; median $=30,34$; varians $=$ 3,98; simpangan baku =1,99; skor maksimum = 36; dan skor minimum = 28, (6) hasil belajar Sejarah Kebudayaan Islam siswa Madrasah Aliyah Negeri Simalungun yang diajar dengan strategi pembelajaran CIRC dan kemandirian belajar rendah diketahui mean $=25,38$; modus $=25$; median $=25,60$; varians $=8,42$; simpangan baku $=2,90$; skor maksimum $=31$; dan skor minimum $=21$, (7) hasil belajar Sejarah Kebudayaan Islam siswa Madrasah Aliyah Negeri Simalungun yang diajar dengan strategi pembelajaran ekspositori dan kemandirian belajar tinggi diketahui mean $=28,43 ;$ modus $=28$; median $=28,30$; varians $=12,26$; simpangan baku $=$ 3,50; skor maksimum $=34$; dan skor minimum $=23$, dan (8) hasil belajar Sejarah Kebudayaan Islam siswa Madrasah Aliyah Negeri Simalungun yang diajar dengan strategi pembelajaran ekspositori dan kemandirian belajar rendah diketahui mean $=26,37 ;$ modus $=25,70$; median $=26$; varians $=14,25$; simpangan baku $=3,77$; skor maksimum $=34$; dan skor minimum $=19$.

Pengujian hipotesis pertama yang berbunyi: hasil belajar Sejarah Kebudayaan Islam siswa Madrasah Aliyah Negeri Simalungun yang diajar dengan strategi pembelajaran CIRC lebih tinggi daripada hasil belajar Sejarah Kebudayaan Islam siswa yang diajar dengan strategi pembelajaran ekspositori terbukti secara empirik. Hal ini berdasarkan perhitungan anava faktorial $2 \times 2$ diperoleh $F_{\text {hitung }}=13,32$ sedangkan nilai $\mathrm{F}_{\text {tabel }}=4,00$ untuk dk $(1,60)$ dan taraf nyata $\alpha=0,05$ ternyata nilai $\mathrm{F}_{\text {hitung }}=$ 13,32 $>\mathrm{F}_{\text {tabel }}=4,00$ sehingga pengujian hipotesis menolak Ho dan menerima Ha.

Pengujian hipotesis kedua yaitu hasil belajar Sejarah Kebudayaan Islam siswa Madrasah Aliyah Negeri Simalungun dengan kemandirian belajar tinggi lebih tinggi dari pada hasil belajar Sejarah Kebudayaan Islam siswa dengan kemandirian belajar rendah terbukti secara empirik. Hal ini berdasarkan perhitungan anava faktorial $2 \times 2$ diperoleh $F_{\text {hitung }}=$ 10,41 sedangkan nilai $F_{\text {tabel }}=4,00$ untuk dk $(1,60)$ dan taraf nyata $\alpha=0,05$. 
ternyata nilai $F_{\text {hitung }}=10,41>F_{\text {tabel }}=4,00$ sehingga hipotesa nol ditolak dan menerima hipotesa alternatif.

Pengujian hipotesis ketiga yaitu: terdapat interaksi antara strategi pembelajaran dan kemandirian belajar dalam mempengaruhi hasil belajar Sejarah Kebudayaan Islam terbukti secara empirik. Hal ini berdasarkan perhitungan anava faktorial $2 \times 2$ diperoleh $F_{\text {hitung }}=12,51$, sedangkan nilai $\mathrm{F}$ tabel $=4,00$ untuk dk $(1,60)$ dan taraf nyata $\alpha=0,05$. ternyata nilai $F_{\text {hitung }}$ $=12,51>F_{\text {tabel }}=4,00$, sehingga hipotesa nol ditolak dan hipotesis alternatif diterima.

\section{PEMBAHASAN}

Rerata hasil belajar Sejarah Kebudayaan Islam siswa Madrasah Aliyah Negeri Simalungun yang diajar dengan strategi pembelajaran CIRC $(\bar{X}=29,32)$ lebih tinggi daripada rerata hasil belajar Sejarah Kebudayaan Islam siswa yang diajar dengan strategi pembelajaran ekspositori $(\bar{X}=27)$. Selanjutnya berdasarkan pengujian hipotesis menunjukkan hasil yang signifikan yaitu harga $F_{\text {hitung }}(13,32)$ lebih besar dari harga $F_{\text {tabel }}(4,00)$. Hal ini menunjukkan bahwa strategi pembelajaran CIRC terbukti efektif dapat meningkatkan hasil belajar Sejarah Kebudayaan Islam siswa Madrasah Aliyah Negeri Simalungun secara keseluruhan baik untuk kelompok siswa dengan kemandirian belajar tinggi maupun kelompok siswa dengan kemandirian belajar rendah. Dengan demikian dapatlah dimaknai bahwa strategi pembelajaran CIRC lebih efektif untuk meningkatkan hasil belajar Sejarah Kebudayaan Islam tanpa memperhatikan kemandirian belajar siswa.

Melalui penerapan strategi pembelajaran CIRC dapat mendorong siswa Madrasah Aliyah Negeri Simalungun untuk aktif belajar karena siswa dapat menghubungkan yang mereka pelajari dengan materi sebelumnya dan struktur kognitif yang sudah dimiliki siswa. Di samping itu strategi pembelajaran CIRC bertujuan menumbuhkan partisipasi siswa dalam memecahkan masalah atau menyelesaikan soal yang diajukan oleh guru dalam pembelajaran, menumbuhkan diskusi di antara siswa dalam mencari penyelesaian atas masalah atau soal tersebut. Oleh karena itu peran guru dalam strategi pembelajaran CIRC lebih dominan sebagai fasilitator yang mengarahkan siswa untuk menemukan dan mengkonstruk sendiri pengetahuannya.

Di samping itu pada strategi pembelajaran CIRC yang dimulai dengan memberikan waktu untuk menganalisis materi atau soal menyebabkan pembelajaran lebih menyenangkan dan membangkitkan 
ketertarikan dan rasa ingin tahu siswa terhadap materi yang disajikan. Hal ini membuat siswa lebih mudah berkonsentrasi pada materi pembelajaran, dan tentu hal ini menjadikan kegiatan pembelajaran yang dilaksanakan menjadi lebih mudah dilaksanakan karena siswa telah tertarik dan berkonsentrasi dalam pembelajaran.

Ketertarikan dan rasa ingin tahu siswa serta telah terkonsentrasinya siswa akan mempermudah siswa memperoleh pengetahuan baru, sehingga pengetahuan tersebut semakin melekat dan tetap dalam ingatan jangka panjang siswa, dan sewaktu-waktu dapat dibangkitkan kembali untuk kebutuhan belajar siswa, terutama saat guru memberikan latihan pada tahap akhir pelaksanaan pembelajaran dan saat pelaksanaan tes hasil belajar di akhir pertemuan pembelajaran.

Hasil penelitian ini dan temuan penelitian lain menunjukkan bahwa strategi pembelajaran CIRC yang dimulai dengan memberikan waktu membaca teks menyebabkan pembelajaran berlangsung lebih menyenangkan dan membangkitkan ketertarikan dan rasa ingin tahu siswa terhadap materi yang disajikan. Hal ini membuat siswa lebih mudah berkonsentrasi pada materi pembelajaran, dan tentu hal ini menjadikan kegiatan membaca yang dilaksanakan menjadi lebih mudah dilaksanakan karena siswa telah tertarik dan berkonsentrasi dalam pembelajaran. Ketertarikan dan rasa ingin tahu siswa serta telah terkonsentrasinya siswa akan mempermudah siswa memperoleh pengetahuan baru, sehingga pengetahuan tersebut semakin melekat dan tetap dalam ingatan jangka panjang siswa, dan sewaktu-waktu dapat dibangkitkan kembali untuk kebutuhan belajar siswa, terutama saat guru memberikan latihan pada tahap akhir pelaksanaan pembelajaran dan saat pelaksanaan tes hasil belajar di akhir pertemuan pembelajaran

Rerata hasil belajar Sejarah Kebudayaan Islam siswa Madrasah Aliyah Negeri Simalungun dengan kemandirian belajar tinggi $(\bar{X}=29,90)$ secara keseluruhan baik yang diajar dengan strategi pembelajaran CIRC dan strategi pembelajaran ekspositori lebih tinggi baik daripada rata-rata hasil belajar Sejarah Kebudayaan Islam siswa Madrasah Aliyah Negeri Simalungun dengan kemandirian belajar rendah $(\bar{X}=26,20)$. Selanjutnya berdasarkan pengujian hipotesis kedua menunjukkan bahwa hasil belajar Sejarah Kebudayaan Islam siswa Madrasah Aliyah Negeri Simalungun dengan kemandirian belajar tinggi lebih tinggi dari pada siswa dengan kemandirian belajar rendah. Hasil analisis statistik membuktikan di mana harga $F_{\text {hitung }}(10,41)$ lebih besar dari harga $F_{\text {tabel }}$ $(4,00)$. 
Hasil ini membuktikan bahwa kemandirian belajar signifikan untuk membedakan hasil belajar Sejarah Kebudayaan Islam siswa. Hal ini dapat dimaklumi karena siswa dengan kemandirian belajar tinggi lebih dapat memahami dan menguasai materi pelajaran Sejarah Kebudayaan Islam dibandingkan siswa dengan kemandirian belajar rendah. Kemandirian belajar pada dasarnya merujuk pada perilaku individu. Akan tetapi, karena perilaku merupakan manifestasi dari kondisi psikologi individu, maka untuk mengetahui tingkat kemandirian belajar siswa perlu memperhatikan aspek-aspek psikologi.

Seorang siswa yang memiliki tingkat kemandirian belajar yang tinggi yang mampu meningkatkan hasil belajarnya, karena siswa tersebut terbiasa untuk bertindak kreatif dan inovatif. Kemandirian belajar tinggi mempunyai makna bagi upaya peningkatan kemampuan dalam belajar sekaligus dalam mencapai hasil belajar yang diperolehnya ketika mengikuti satu pelajaran. Selain itu siswa dengan kemandirian belajar tinggi akan bertindak menurut buah pikirannya sendiri sesuai dengan kemampuannya pada akhirnya akan bermuara kepada kematangan pola pikir dan pola belajar serja kemauan belajar yang kuat untuk memperoleh hasil belajar yang lebih baik

Hasil penelitian ini dan temuan penelitian lainnya menunjukkan bahwa tingkat kemandirian belajar yang terinternalisasi dalam diri diri seorang siswa akan memberikan dukungan terhadap kegiatan belajar yang dilakukannya. Kemandirian belajar sebagai satu kekuatan pada diri individu dalam melakukan sesuatu tanpa tergantung orang lain tentunya mempunyai makna yang berarti bagi seorang siswa dalam merencanakan, mengelola dan menyelesaikan kegiatan belajarnya. Dapat diprediksikan bahwa apabila tingkat kemandirian belajar seorang siswa tinggi, maka dapar diharapkan siswa tersebut akan dapat mencapai hasil yang lebih baik dari rekannya. Jadi kemandirian belajar seorang siswa mempunyai makna bagi upaya peningkatan kemampuan dalam belajar sekaligus dalam kerangka mencapai hasil belajar yang diperolehnya. Siswa dengan tingkat kemandirian belajar tinggi ditandai dengan kecenderungan: (1) tidak bergantung pada orang lain, (2) berinisiatif, (3) motivasi belajar tinggi dan (4) tidak mudah menyerah, sedangkan siswa dengan tingkat kemandirian rendah ditandai dengan kecenderungan: (1) selalu bergantung pada orang lain, (2) kurang inisiatif, (3) motivasi belajar rendah, (4) cepat menyerah.

Rerata hasil belajar Sejarah Kebudayaan Islam siswa Madrasah Aliyah Negeri Simalungun yang diajar dengan strategi pembelajaran 
CIRC dan kemandirian belajar tinggi $\quad(\bar{X}=31,38)$ lebih tinggi daripada hasil belajar Sejarah Kebudayaan Islam siswa dengan kemandirian belajar rendah $(\bar{X}=25,38)$. Sedangkan pada strategi pembelajaran ekspositori, rata-rata hasil belajar Sejarah Kebudayaan Islam siswa dengan kemandirian belajar tinggi ( $\bar{X}=28,43$ ) lebih tinggi daripada hasil belajar Sejarah Kebudayaan Islam siswa dengan kemandirian belajar rendah $(\bar{X}$ $=$ 26,37). Selanjutnya berdasarkan pengujian hipotesis ketiga menunjukkan terdapat interaksi antara strategi pembelajaran dan kemandirian belajar dalam mempengaruhi hasil belajar Sejarah Kebudayaan Islam siswa Madrasah Aliyah Negeri Simalungun, di mana hasil analisis statistik membuktikan di mana harga $F_{\text {hitung }}(12,51)$ lebih besar dari harga $\mathrm{F}_{\text {tabel }}(4,00)$.

\section{SIMPULAN}

Simpulan yang dapat ditarik dari hasil penelitian adalah sebagai berikut: (1) rata-rata hasil belajar Sejarah Kebudayaan Islam siswa yang diajar dengan strategi pembelajaran CIRC lebih tinggi dibandingkan dengan rata-rata hasil belajar Sejarah Kebudayaan Islam siswa Madrasah Aliyah Negeri Simalungun yang diajar dengan strategi pembelajaran ekspositori. Dengan demikian strategi pembelajaran CIRC lebih efektif diterapkan dalam pembelajaran Sejarah Kebudayaan Islam guna meningkatkan hasil belajar Sejarah Kebudayaan Islam siswa Madrasah Aliyah Negeri Simalungun tanpa memperhatikan adanya perbedaan kemandirian belajar, (2) rata-rata hasil belajar Sejarah Kebudayaan Islam siswa dengan kemandirian belajar tinggi yang diajar dengan strategi pembelajaran CIRC maupun strategi pembelajaran ekspositori lebih tinggi dibandingkan dengan rata-rata hasil belajar Sejarah Kebudayaan Islam siswa dengan kemandirian belajar rendah, dan (3) terdapat interaksi antara strategi pembelajaran dan kemandirian belajar siswa yang memberikan perbedaan pengaruh terhadap hasil belajar Sejarah Kebudayaan Islam. Perbedaan pengaruh tersebut adalah: (a) hasil belajar Sejarah Kebudayaan Islam siswa yang diajar dengan strategi pembelajaran CIRC lebih tinggi dibandingkan hasil belajar Sejarah Kebudayaan Islam siswa yang diajar dengan strategi pembelajaran ekspositori, (b) hasil belajar Sejarah Kebudayaan Islam siswa dengan kemandirian belajar tinggi lebih tinggi dibandingkan siswa dengan kemandirian belajar rendah, (c) hasil belajar Sejarah Kebudayaan Islam siswa yang diajar dengan strategi pembelajaran CIRC dan kemandirian belajar tinggi lebih 
tinggi dibandingkan siswa dengan kemandirian belajar rendah, (d) hasil belajar Sejarah Kebudayaan Islam siswa dengan yang diajar dengan strategi pembelajaran ekspositori dengan kemandirian belajar tinggi lebih tinggi dibandingkan siswa dengan kemandirian belajar rendah, (e) hasil belajar Sejarah Kebudayaan Islam siswa yang diajar dengan strategi pembelajaran CIRC dan kemandirian belajar tinggi lebih tinggi daripada hasil belajar Sejarah Kebudayaan Islam siswa yang diajar dengan strategi pembelajaran ekspositori dan kemandirian belajar tinggi, dan (f) hasil belajar Sejarah Kebudayaan Islam siswa yang diajar dengan strategi pembelajaran CIRC dan kemandirian belajar rendah lebih rendah daripada hasil belajar Sejarah Kebudayaan Islam siswa yang diajar dengan strategi pembelajaran ekspositori dan kemandirian belajar rendah.

\section{REKOMENDASI}

Rekomendasi yang disampaikan sebagai berikut: (1) strategi pembelajaran dan karakteristik siswa merupakan suatu komponen yang dapat menentukan dan mempengaruhi hasil belajar. Oleh karena itu guru sebagai perancang pembelajaran memperhatikan strategi pembelajaran dan karakteristik siswa dalam merancang pembelajaran sehingga dengan demikian guru dapat menetapkan pilihan strategi pembelajaran yang lebih sesuai dengan karakteristik siswa untuk dilaksanakan, (2) karakteristik siswa yang diteliti dari penelitian ini hanya terbatas kepada kemandirian belajar. Untuk itu kepada peneliti lain disarankan untuk meneliti karakteristik siswa yang lain misalnya kemampuan awal, retensi, motivasi belajar, gaya belajar, dan (3) strategi pembelajaran CIRC diterapkan pada mata pelajaran Sejarah Kebudayaan Islam dan pada ranah kognitif, disarankan untuk peneliti lain dapat meneliti dalam bidang studi lainnya.

\section{DAFTAR PUSTAKA}

Anderson, O.W. dan Krathwohl, (2001) A Taxonomy for Learning, Teaching, and Assesing: A Revision of Bloom's Taxonomy of Educational Objectives, New York; Longman.

Arikunto, Suharsimi. (2005) Dasar-Dasar Evaluasi Pendidikan. Jakarta: Bumi Aksara.

Burns, R.B. (1979) Konsep Diri, Teori., Pengalaman, Perkembangan dan Prilaku, Jakarta: Arcan. 
DePorter, B., Reardon, M., dan Nourie. S.S. (2003). Quantum Teaching, Orchestrating Student Succes. Penerjemah: Ary Nilandari. Quantum Teaching Mempraktikkan Quantum Learning Di Ruang-Ruang Kelas. Bandung: Kaifa

Djamarah, Syaiful Bahri dan Zain, Awan. (2002) Strategi Belajar Mengajar. Jakarta: Rineka Cipta.

Gagne, Robert .M. (1977) The Conditioning of Learning. New York: Hall, Rinehort and Winston.

Gredler, B.E.Margaret. (1994) Belajar dan Membelajarkan. Jakarta: Rajawali.

Gulo, W. (2008) Strategi Belajar Mengajar. Jakarta: Grasindo.

Hergenhahn, B.R dan Olson, M.H. (20080 Theories of Learning (Teori Belajar). Alih Bahasa: Tri Wibowo BS. Jakarta: Kencana Prenada Media Group.

Johnson, R.C dan Medinnus, GR. (1989) Behaviour Child Psychology and Development, New York: Johan Willy and Sons Inc.

Kemp. Jerold .E. (1994) Proses Perancangan Pengajaran. Terjemahan: Asril Mardjohan Bandung: ITB.

Lie, Anita. (2004) Cooperative Learning. Mempraktekkan Cooperative Learning di Ruang-ruang kelas. Jakarta: Grasindo.

Pribadi, Benny A. (2001) Model Desain Sistem Pembelajaran. Jakarta: Dian Rakyat.

Pudjijogyanti, Clara R. (1988) Konsep Diri Dalam Pendidikan. Jakarta: Arcan.

Riyanto, Y. (2010) Paradigma Baru Pembelajaran. Jakarta: Kencana Prenada Media Group.

Rusmono, (2012) Strategi Pembelajaran Dengan Problem Based Learning Itu Perlu Untuk Meningkatkan Porfesionalitas Guru. Bogor: Ghalia Indonesia.

Sagala, Syaiful. (2012) Konsep dan Makna Pembelajaran. Bandung: Alfabeta.

Sanjaya, Wina. (2014) Strategi Pembelajaran, Berorientasi Standar Proses Pendidikan. Jakarta: Prenada Media Group.

Siregar, Eveline dan Nara, Hartini. (2011) Teori Belajar Dan Pembelajaran. Bogor: Ghalia Indonesia.

Slavin, Robert E. (2005) Cooperative Learning, Teori, Riset dan Praktek. Penerjema Narulita Yusron, Bandung: Nusa Media.

Yamin, Martinis dan Sanan. Jamilah Sabri. Panduan Pendidikan Anak Usia Dini. Jakarta: Gaung Persada Pers. 2010.

Yaumi, Muhammad. (2013) Prinsip-Prinsip Desain Pembelajaran. Jakarta: Prenada Media Group. 